\title{
Utilization of Sugarcane By-Products as Complete Rations for Milk Production in Buffaloes
}

\author{
S.B. Pakala Venkata ${ }^{1}$, R. Prasanna Kumar ${ }^{2}$, M. Sahitya Rani $^{3^{*}}$ and E. Raghava Rao \\ ${ }^{1}$ Researcher, Singapore \\ ${ }^{2}$ Krishi Vigyan Kendra, Mamnoor, Warangal District, Telangana State-506166, India \\ ${ }^{3}$ Department of Livestock Products Technology, College of Veterinary Science, Koratla, \\ Jagitial District, Telangana state-505326, India \\ ${ }^{4}$ Director of Research, SVVU, Tirupati, Andhra Pradesh state, India
}

*Corresponding author

\begin{abstract}
A B S T R A C T
Key words

Cost economics,

Lactation trial, Murrah buffaloes, Milk yield,

Milk quality, and

sugar cane by products

Article Info

Accepted:

26 January 2018

Available Online:

10 February 2018

A lactation trial was conducted to study the effect of feeding sugarcane by products based complete ration on milk yield and milk quality as well, of murrah buffaloes. Seven rations ( six complete rations were formulated by using sugarcane by-products and other crop residues and balanced concentrate mixture in the mash form and one conventional ration comprised with hybrid Napier and concentrate mixture) were prepared and fed 28 Murrah buffaloes distributed equally into seven groups in Randomized Block Design for a period of 180 days. It was found that the buffaloes performed equally well when compared to control i.e. traditional system of feeding (green, dry fodder and concentrate mixture fed separately) and supported the milk production up to $12.28 \mathrm{~kg}$ per day with fat $\%$ of 8.1 compared to $9.32 \mathrm{~kg}$ of milk production with $8.39 \%$ of fat in buffaloes of control group. The feed cost per kg milk production was Rs. $4.00-5.37$ at an intake level of 3.33 $\mathrm{kg} / 100 \mathrm{~kg}$ body weight in sugarcane based complete diets against Rs. 5.34 at an intake level of $2.79 \mathrm{~kg}$ per $100 \mathrm{~kg}$ body weight in buffaloes fed with control diet. Hence, the sugarcane by-products and other crop residues instead of wasting and burning in the fields, they can be incorporated up to the level of $30 \%$ to formulate complete rations to feed livestock for economic milk production.
\end{abstract}

\section{Introduction}

Integration of livestock production system with crop production has got great relevance for optimising returns from the same land by way of getting additional revenue through the utilization of crop residues or agro-industrial by-products that are locally available with the farmer. This serves as a sustainable source of income to the farmer even when crop production fails in certain situations. In addition to availability of several by-products like sugarcane tops, bagasse, pith and molasses from sugarcane based production system, several other crop residues and byproducts can also be made available in the area which can be recycled for augmenting animal productivity. The most important by- 
products of sugarcane farming are sugarcane tops and sugarcane trash and those of industry are sugarcane bagasse, molasses, and sugarcane sludge and press mud. India stands $2^{\text {nd }}$ in sugarcane production in the world next to Brazil with an annual production of 265 million tons. Hence there is a necessity to use the by-products of sugarcane farming and sugar industry to livestock feeding systems since they have all the nutrients required for large animal feeding.

\section{Materials and Methods}

Required quantity of sugarcane(Sacharam afficinarum)by-products viz., sugarcane (7805) tops and trash were procured from the farmers fields of sugarcane production areas surrounding the Buffalo Research Station, Venkataramannagudem, and remaining agricultural crop residues like maize stover (Zea mays), jowar straw (Sorghum bicolor), Paddy straw (Oryza sativa) and sunhemp hay (Crotalaria juncea) and Pillipesara (Phasiolus mongo) were procured within the Research Station and paddy straw was procured from the Agricultural Research Station, Maruteru. The concentrate feed ingredients were procured from the local market. The method for urea enrichment of sugarcane trash was followed as per suggested (Mojumdar et al., 2003).

Five hundred $\mathrm{kg}$ of sugarcane trash was treated with $4 \%$ urea at 40 per cent moisture level, which was compacted in a shed of $3.6 \mathrm{x}$ $2.0 \times 1.2 \mathrm{~m}$ walls with concrete floor. After 21 days of ensiling, the polythene sheet was removed and the treated trash was air dried and ground prior to the preparation of complete ration- $\mathrm{V}$ for feeding of $5^{\text {th }}$ group milch buffaloes in the experiment. The treated sugarcane trash was fed next day to minimize the insistent effect of residual ammonia entrapped in the treated trash when fed to animals (Dayal et al., 1997).
Complete rations were formulated by using the sugarcane by-products and other crop residues for lactation experiments. These complete rations were formulated based on in vitro studies. The selected complete rations were designated in the experiment as CR-I, CR-II, CR-III, CR-IV, CR-V and CR-VI, respectively. Control ration comprised of green fodder and concentrate mixture in milch buffaloes (Table 1).

The lactation trial of 180 days was conducted on Murrah buffaloes at Buffalo Research Station, Venkataramannagudem, West Godavari District, A.P. Twenty eight lactating Murrah buffaloes, which were in second and third lactation were selected and distributed randomly into seven equal groups in Randomized Block Design (RBD) considering daily milk yield, order of lactation and stage of lactation. The buffaloes were producing an average of $7.18 \pm 0.34 \mathrm{~kg}$ of milk per day at the start of experiment.

Complete rations were formulated using sugarcane tops, untreated/urea treated sugarcane trash and locally available other crop residues like maize stover, jowar straw and balanced concentrate mixture for experimental rations and green fodder and concentrate mixture for control ration. Vitamin $\left(\mathrm{AD}_{3}\right)$ mixture was added to take care of vitamin A requirement for the animals in all groups except control group. Basing on the body weight of the animals, milk yield and average percentage of milk fat, the buffaloes were fed according to requirements suggested (Kearl, 1982). $20 \mathrm{~kg}$ of complete ration was offered ad libitum to each animal basing on the milk yield and maintenance requirement during the experimental period. For control ration ad-libitum feeding of green fodder (Hybrid Napier) along with 2.5 to $5.0 \mathrm{~kg}$ of concentrate mixture was offered to each animal basing on milk yield (@ 1 kg concentrate mixture for every $2.0 \mathrm{~kg}$ of milk 
yield. The chemical composition of sugarcane based complete rations, Green fodder and Concentrate mixture was given in Table 2 . Representative samples of milk from individual buffaloes were collected into sterile milk sample bottles after each milking both morning and evening for analysis at fortnightly intervals. These milk samples were subjected to determination of fat, SNF and total solids. The milk samples were also collected at the commencement of the experiment and analysed for fat, SNF and total solids.

The samples collected from the experimental buffaloes were analysed for fat $\%, \mathrm{SNF}$ and total solids at fortnightly intervals.

The milk fat was determined by the Gerber's method as per ISI 1977 IS 1224 (Part I), using special Butyrometer and pipette with ISI marking.

The SNF was calculated by using gravimetric method (ISI 1982 IS: 10083-1982) based on estimation of specific gravity using corrected lactometer reading (CLR). Lactometer standardized at $20^{\circ} \mathrm{C}$ was used according to the temperature of milk in Fahrenheit using ISI chart.

$\mathrm{SNF} \%=\frac{\mathrm{CLR}+0.25 \mathrm{~F}+0.6}{------}$

Where

CLR $=$ Corrected Lactometer Reading, $\mathrm{F}=$ Fat percentage

From the milk yield and fat yield of animals 4 per cent fat corrected milk yield (FCM) was calculated as per Rice et al., (1970).

$6 \% \mathrm{FCM}=0.308 \mathrm{X}$ Total Milk Yield +11.54 $\mathrm{X}$ Total Fat Yield (kg)
The total solids content of the milk was also arrived by the addition of fat and SNF percentages.

The experimental data were subjected to statistical analysis according to the Snedecor G W and Cochran W C 1976 procedures.

\section{Results and Discussion}

The Performance of lactating Murrah buffaloes fed on various sugarcane by products based complete rations was presented in Table 3. The total DMI $(\mathrm{Kg})$ varied significantly $(p<0.01)$ among the treatment groups and observed to be highest $(18.00 \pm 0.01)$ in the buffaloes fed CR-VI.

Feed efficiency (Kg DM consumed/Kg Milk produced) did not differ significantly among the buffaloes fed various rations but was comparable with each other.

Further, these results were also comparable with the research findings in graded Murrah buffaloes (Reddy et al., 2003, Raghava Rao et al., 2017) and in crossbred cows (Reddy et al., 1996; Raghava Rao and Gupta, 1991). This might be attributed to better digestibility of nutrients and improved utilization of complete feed for milk production compared to conventional ration.

The least Cost $/ \mathrm{Kg}$ complete ration was (Rs 2.83) for CR IV and the least cost of complete ration/Kg milk produced was (Rs.3.99) for CR $\mathrm{V}$ which was significantly lower than the control (Rs 9.25 and Rs. 5.34 respectively). Lower feed cost $/ \mathrm{kg}$ milk production was also reported in lactating buffaloes (Rangaiah, 2004) fed on differently processed complete diets and in crossbred cows (Reddy et al., 1996) fed on fodder based complete diets and in graded Murrah buffaloes (Reddy et al., 2003) fed differently processed complete diets. 
Table.1 Per cent ingredient composition of complete Rations (CR) formulated using Sugarcane by-products with other crop residues and other concentrate feed ingredients for feeding of milch buffaloes

\begin{tabular}{|l|l|l|l|l|l|l|l|}
\hline Name of Ingredient & CR -1 & CR -2 & CR -3 & CR -4 & CR - 5 & CR - 6 & Control* $^{*}$ \\
\hline Sugarcane tops (dried) & 40 & 30 & 40 & 40 & 40 & 30 & - \\
\hline Sugarcane trash & 20 & - & - & - & - & & - \\
\hline Sugarcane trash(urea treated) & - & - & - & - & - & 30 & \\
\hline Maize stover & - & 30 & - & - & - & & - \\
\hline Jowar straw (Kadbi) & - & - & 20 & - & - & & - \\
\hline Paddy straw & -- & -- & - & 20 & -- & & - \\
\hline Sunhemp Hay & -- & -- & -- & -- & 20 & & - \\
\hline Maize grain & 5 & 5.80 & 9.80 & -- & 7.80 & 6.80 & - \\
\hline Bajra grain & & - & & 5.80 & & & - \\
\hline Jowar grain & & - & & & & & - \\
\hline Groundnut cake & 16.80 & 8.00 & 14.00 & -- & -- & 8.00 & - \\
\hline Cottonseed cake & 1.50 & & -- & -- & 11.00 & & - \\
\hline Sunflower cake & 2.50 & & -- & 5.00 & -- & & - \\
\hline Gingily cake & & 2.00 & 2.00 & 3.50 & 5.00 & 8.00 & - \\
\hline Blackgram chunni & 4.50 & 8.50 & 5.50 & -- & 15.00 & & - \\
\hline Greengram Chunni & - & & & 8.00 & -- & & - \\
\hline Cowpea chunni & - & - & - & - & - & 16.00 & \\
\hline Mineral Mixture & 0.80 & 0.80 & 0.80 & 0.80 & 0.80 & 0.80 & - \\
\hline Salt & 0.40 & 0.40 & 0.40 & 0.40 & 0.40 & 0.40 & - \\
\hline Vitamin A, D3 & $20 \mathrm{~g}$ & $20 \mathrm{~g}$ & $20 \mathrm{~g}$ & $20 \mathrm{~g}$ & $20 \mathrm{~g}$ & $20 \mathrm{~g}$ & \\
\hline
\end{tabular}

Table.2 Chemical composition of sugarcane based complete rations, green fodder and concentrate mixture

\begin{tabular}{|l|l|l|l|l|l|l|l|l|}
\hline Parameter & CR-I & CR-II & $\begin{array}{l}\text { CR- } \\
\text { III }\end{array}$ & $\begin{array}{l}\text { CR- } \\
\text { IV }\end{array}$ & CR-V & CR-VI & $\begin{array}{l}\text { Green } \\
\text { fodder* }\end{array}$ & $\begin{array}{l}\text { Concentrate } \\
\text { mixture }\end{array}$ \\
\hline Dry matter & 88.98 & 89.40 & 89.01 & 88.89 & 88.03 & 88.40 & 28.0 & 95.01 \\
\hline Organic matter & 95.27 & 92.93 & 93.90 & 92.96 & 94.01 & 93.79 & 83.40 & 93.11 \\
\hline Crude protein & 12.76 & 12.58 & 12.68 & 12.11 & 12.84 & 12.51 & 12.50 & 17.85 \\
\hline Crude fibre & 20.68 & 26.25 & 25.94 & 25.69 & 24.11 & 26.68 & 31.50 & 9.70 \\
\hline Ether extract & 01.77 & 02.54 & 02.12 & 01.87 & 01.70 & 02.72 & 01.90 & 5.10 \\
\hline Total ash & 04.74 & 07.08 & 06.10 & 07.04 & 05.99 & 06.21 & 16.60 & 6.89 \\
\hline Nitrogen free- extract & 60.05 & 51.55 & 53.16 & 53.29 & 53.36 & 51.88 & 37.50 & 60.46 \\
\hline Neutral detergent fiber & 39.54 & 39.83 & 42.27 & 48.88 & 52.55 & 51.01 & 79.50 & 23.17 \\
\hline Acid detergent fiber & 27.22 & 34.59 & 31.68 & 36.24 & 43.28 & 38.49 & 55.60 & 15.07 \\
\hline Cellulose & 19.65 & 25.39 & 23.51 & 27.21 & 31.88 & 24.11 & 39.40 & 09.97 \\
\hline Hemicellulose & 12.32 & 05.24 & 10.59 & 12.64 & 09.27 & 12.52 & 23.90 & 08.10 \\
\hline Lignin & 04.78 & 05.15 & 06.98 & 06.19 & 08.03 & 09.55 & 12.80 & 02.37 \\
\hline Silica & 02.77 & 04.05 & 01.18 & 02.83 & 03.35 & 04.83 & 03.40 & 02.73
\end{tabular}


Table.3 Performance of lactating Murrah buffaloes fed on various sugarcane by-products based complete rations

\begin{tabular}{|c|c|c|c|c|c|c|c|c|}
\hline \multirow{2}{*}{$\begin{array}{l}\text { Sl. } \\
\text { No }\end{array}$} & \multirow[t]{2}{*}{ Parameter } & \multirow[t]{2}{*}{ Control } & \multicolumn{6}{|c|}{ Experimental rations } \\
\hline & & & CR-I & CR-I I & CR-III & CR-IV & CR-V & CR-VI \\
\hline 1. & Live weight (Kg) & $\begin{array}{c}560.0 \\
\pm 13.65\end{array}$ & $\begin{array}{l}580.25 \\
\pm 12.32\end{array}$ & $\begin{array}{l}600.67 \\
\pm 16.73\end{array}$ & $\begin{array}{l}530.62 \\
\pm 23.32\end{array}$ & $\begin{array}{l}587.80 \\
\pm 16.11\end{array}$ & $\begin{array}{l}559.20 \\
\pm 19.50\end{array}$ & $\begin{array}{l}591.87 \\
\pm 18.50\end{array}$ \\
\hline 2. & Total DMI (Kg) & $\begin{array}{l}15.64^{c} \\
\pm 0.27\end{array}$ & $\begin{array}{r}17.54^{\mathrm{a}} \\
\pm 0.12\end{array}$ & $\begin{array}{r}17.71^{\mathrm{a}} \\
\pm 0.09\end{array}$ & $\begin{array}{l}17.70^{\mathrm{a}} \\
\pm 0.10\end{array}$ & $\begin{array}{l}16.82^{b} \\
\pm 0.32\end{array}$ & $\begin{array}{l}17.59^{\mathrm{a}} \\
\pm 0.22\end{array}$ & $\begin{array}{l}18.00^{\mathrm{a}} \\
\pm 0.01\end{array}$ \\
\hline 3. & $\begin{array}{l}\text { DMI }(\mathrm{Kg} / 100 \mathrm{Kg} \\
\text { Body Wt. }(\mathrm{Kg})\end{array}$ & $\begin{array}{l}2.79^{d} \\
\pm 0.04\end{array}$ & $\begin{array}{l}3.13^{b} \\
\pm 0.02\end{array}$ & $\begin{array}{l}3.05^{c} \\
\pm 0.01\end{array}$ & $\begin{array}{l}3.33^{\mathrm{a}} \\
\pm 0.02\end{array}$ & $\begin{array}{l}2.85^{\mathrm{d}} \\
\pm 0.05\end{array}$ & $\begin{array}{l}3.14^{b} \\
\pm 0.08\end{array}$ & $\begin{array}{l}3.00^{c} \\
\pm 0.02\end{array}$ \\
\hline 4. & $\begin{array}{l}\text { Avg. Daily milk } \\
\text { yield }(\mathrm{Kg})\end{array}$ & $\begin{array}{l}9.20 \\
\pm 0.40\end{array}$ & $\begin{array}{l}11.60 \\
\pm 1.11\end{array}$ & $\begin{array}{l}11.90 \\
\pm 0.99\end{array}$ & $\begin{array}{r}12.15 \\
\pm 0.44\end{array}$ & $\begin{array}{l}11.85 \\
\pm 0.50\end{array}$ & $\begin{array}{r}12.05 \\
\pm 0.30\end{array}$ & $\begin{array}{l}11.80 \\
\pm 0.63\end{array}$ \\
\hline 5. & $\begin{array}{l}\text { Feed efficiency } \\
(\mathrm{Kg} \quad \mathrm{DM} \\
\text { consumed/Kg } \\
\text { Milk produced })\end{array}$ & $\begin{array}{l}1.71 \\
\pm 0.08\end{array}$ & $\begin{array}{l}1.57 \\
\pm 0.17\end{array}$ & $\begin{array}{l}1.51 \\
\pm 0.11\end{array}$ & $\begin{array}{l}1.46 \\
\pm 0.05\end{array}$ & $\begin{array}{l}1.42 \\
\pm 0.08\end{array}$ & $\begin{array}{l}1.45 \\
\pm 0.03\end{array}$ & $\begin{array}{l}1.50 \\
\pm 0.07\end{array}$ \\
\hline 6. & $\begin{array}{lr}\text { Cost } & / \mathrm{Kg} \\
\text { complete ration } \\
(\mathrm{Rs})\end{array}$ & $9.25^{\mathrm{a}}$ & $3.41^{\mathrm{b}}$ & $3.17^{\mathrm{d}}$ & $3.33^{c}$ & $2.83^{\mathrm{f}}$ & $2.73^{\mathrm{g}}$ & $2.80^{\mathrm{e}}$ \\
\hline 7. & $\begin{array}{l}\text { Cost of complete } \\
\text { ration / Kg milk } \\
\text { produced (Rs.) }\end{array}$ & $\begin{array}{l}5.34^{\mathrm{a}} \\
\pm 0.25\end{array}$ & $\begin{array}{r}5.37^{\mathrm{a}} \\
\pm 0.59\end{array}$ & $\begin{array}{r}4.83^{\mathrm{a}} \\
\pm 0.35\end{array}$ & $\begin{array}{l}4.87^{\mathrm{a}} \\
\pm 0.17\end{array}$ & $\begin{array}{l}4.04^{\mathrm{ab}} \\
\pm 0.22\end{array}$ & $\begin{array}{l}3.99^{\mathrm{ab}} \\
\pm 0.08\end{array}$ & $\begin{array}{l}4.25^{\mathrm{ab}} \\
\pm 0.21\end{array}$ \\
\hline
\end{tabular}

Means bearing different super scripts in the row differ significantly $(P<0.01)$

Table.4 Effect of feeding various sugarcane by-products based complete rations on average milk yield and quality in lactating Murrah buffaloes

\begin{tabular}{|c|c|c|c|c|c|c|c|c|}
\hline \multirow{2}{*}{$\begin{array}{l}\text { S1. } \\
\text { No }\end{array}$} & \multirow[t]{2}{*}{ Parameter } & \multirow[t]{2}{*}{ Control } & \multicolumn{6}{|c|}{ Experimental rations } \\
\hline & & & CR-I & CR-I I & CR-III & CR-IV & CR-V & CR-VI \\
\hline 1. & Milk yield (Kg) & $\begin{array}{c}9.32^{b} \\
\pm 0.23\end{array}$ & $\begin{array}{l}11.62^{\mathrm{a}} \pm \\
0.44\end{array}$ & $\begin{array}{l}11.95^{\mathrm{a}} \\
\pm 0.47\end{array}$ & $\begin{array}{l}12.28^{a} \\
\pm 0.58\end{array}$ & $\begin{array}{l}11.12^{\mathrm{a}} \\
\pm 1.06\end{array}$ & $\begin{array}{l}11.69^{\mathrm{a}} \\
\pm 0.47\end{array}$ & $\begin{array}{l}11.97^{\mathrm{a}} \\
\pm 0.44\end{array}$ \\
\hline 2. & Fat $(\%)$ & $\begin{array}{c}8.39 \\
\pm 0.16\end{array}$ & $\begin{array}{c}8.06 \\
\pm 0.19\end{array}$ & $\begin{array}{c}7.92 \\
\pm 0.24\end{array}$ & $\begin{array}{c}8.10 \\
\pm 0.21\end{array}$ & $\begin{array}{c}7.92 \\
\pm 0.22\end{array}$ & $\begin{array}{c}7.99 \\
\pm 0.21\end{array}$ & $\begin{array}{c}8.33 \\
\pm 0.28\end{array}$ \\
\hline 3. & Fat yield (Kg) & $\begin{array}{l}0.78^{\mathrm{b}} \\
\pm 0.02\end{array}$ & $\begin{array}{l}0.93^{\mathrm{a}} \\
\pm 0.03\end{array}$ & $\begin{array}{l}0.97^{\mathrm{a}} \\
\pm 0.06\end{array}$ & $\begin{array}{l}0.93^{\mathrm{a}} \\
\pm 0.09\end{array}$ & $\begin{array}{l}0.93^{\mathrm{a}} \\
\pm 0.03\end{array}$ & $\begin{array}{l}0.95^{\mathrm{a}} \\
\pm 0.05^{2}\end{array}$ & $\begin{array}{l}0.98^{\mathrm{a}} \\
\pm 0.03\end{array}$ \\
\hline 4. & $4 \% \mathrm{FCM}$ & $\begin{array}{l}16.05 \\
\pm 0.77\end{array}$ & $\begin{array}{l}18.63 \\
\pm 0.70\end{array}$ & $\begin{array}{l}19.25 \\
\pm 1.10\end{array}$ & $\begin{array}{l}19.04 \\
\pm 1.6\end{array}$ & $\begin{array}{l}18.72 \\
\pm 0.71\end{array}$ & $\begin{array}{l}19.07 \\
\pm 1.00\end{array}$ & $\begin{array}{l}19.62 \\
\pm 0.55\end{array}$ \\
\hline 5. & $\operatorname{SNF}(\%)$ & $\begin{array}{l}10.11 \\
\pm 0.03\end{array}$ & $\begin{array}{l}10.04 \pm \\
0.05\end{array}$ & $\begin{array}{l}10.18 \\
\pm 0.06\end{array}$ & $\begin{array}{l}10.05 \\
\pm 0.06\end{array}$ & $\begin{array}{l}10.06 \\
\pm 0.07\end{array}$ & $\begin{array}{l}10.13 \\
\pm 0.05\end{array}$ & $\begin{array}{l}10.12 \\
\pm 0.07\end{array}$ \\
\hline 6. & Total solids (\%) & $\begin{array}{l}18.54 \\
\pm 0.17\end{array}$ & $\begin{array}{l}16.69 \\
\pm 1.40\end{array}$ & $\begin{array}{l}19.30 \\
\pm 0.35\end{array}$ & $\begin{array}{l}18.14 \\
\pm 0.28\end{array}$ & $\begin{array}{l}16.44 \\
\pm 1.43\end{array}$ & $\begin{array}{l}18.16 \\
\pm 0.27\end{array}$ & $\begin{array}{l}18.46 \\
\pm 0.34\end{array}$ \\
\hline
\end{tabular}

Means bearing different super scripts in the row differ significantly $(P<0.01)$ 
The effect of feeding of various sugarcane byproducts based complete rations on average milk yield and quality in lactating Murrah buffaloes was presented in Table 4. The milk yield of the buffaloes fed various experimental rations was significantly higher than the control group. The highest milk yield was observed with the buffaloes fed CR III $(12.28 \mathrm{~kg})$ than the control group $(9.32 \mathrm{~kg})$. Milk yield in buffaloes recorded in this study was in accordance with the results in milch buffaloes fed on maize cobs based complete diets and in dairy animals fed on sugar beet pulp and maize gluten diets (Colin Schoellen, 1995; Reddy and Reddy 1999b). The fat yields were significantly $(\mathrm{p}<0.05)$ higher by 25.0, 28.95, 30.26, 26.32, 26.32 and 25.0 per cent units in buffaloes fed with CR-I, CR-II, CR-III, CR-IV, CR-V and CR-VI when compared to buffaloes fed with controlled ration. These results were corroborated with the findings in crossbred cows fed with fodder based complete rations (Reddy et al., 1996). No significant difference was observed in the fat $\%$, solid non-fat $\%$ and Total solids $\%$ of the milk produced from buffaloes fed various experimental rations. The fat percentages ranged from 7.92 to $8.39 \%$. The results of the present study were in agreement with the findings of the some of the research workers (Mojumdar et al., 2003; Raghava Rao and Gupta, 1991; Reddy et al., 1996; Reddy and Reddy, 1999b; Reddy et al., 2003; Sreedhar et al., 1997) in buffaloes and cows fed on various agricultural by-products based complete rations.

\section{References}

Colin Schoellen, O., Z.S. Jurjan, J.N. Gardeur and Laurent F. 1995. Influence of the type of concentrate on zoo technical performance of dairy cows receiving a complete diet. Annales de Zootechnie 44(4): 359-372.
Dayal, S.J., N. Krishna and Raghava Rao. 1997. Standardization of ureaammoniation techniques for enriching palm press fibre as roughages source for enriching buffaloes. Nutritional Constraints and strategies for sustainable animal Production held at Chennai from $12^{\text {th }}-14^{\text {th }}$ December.

ISI 1977 IS 1224 (Part I) Fat determination of milk by Gerber's method. Indian Standards Institution, New Delhi

ISI 1982 IS: 10083-1982. Method of test for determination of SNF (Solids not fat) in milk by the use of lactometer. Indian Standards Institution, New Delhi.

Kearl, L.C., 1982. Nutrients requirements of ruminants in developing countries. International Feedstuffs Institute. Utah Agricultural Experimental Station, Utah State University, Logan, USA, p 47.

Mojumdar, A.B., M.M. Das, S.B. Maity and Anil Kumar. 2003. Nutrient utilization and performance of crossbred cows fed urea treated straw based diets. Animal Nutrition and Feed Technology 3:173178.

Raghava Rao, E., and Gupta B.S. 1991. Growth rate of crossbred calves as influenced by feeding high levels of urea/ammonia and / or steam treated bagasse. Proceedings of First International Animal Nutrition workers Conference held at Bangalore from $23^{\text {rd }}-28^{\text {th }}$ September, 91.

Raghava Rao, E., R. Prasanna Kumar, S.B. Pakala Venkata and Sahitya Rani M. 2017. Utilization of Sugarcane ByProducts as Complete Rations for Meat Production in Buffaloes. International Journal of Research in Engineering and Applied Sciences. Vol. 7 Issue 1. January7. pp. 38 45.

Rangaiah, B., 2004. Effect of differently processed complete diets containing water washed and urea treated neem seed cake on performance of lactating 
murrah buffaloes. MVSc thesis submitted to Acharya NG Ranga Agricultural University, Hyderabad.

Reddy, G.V.N., and Reddy, M.R. 1999b. Effect of feeding extruded complete diet containing maize cob in Ongole bull calves. Indian Journal of Animal Nutrition 16:210-214.

Reddy, G.V.N., M.R. Reddy, and Das, T.C. 1996. Effect of feeding of fodder based complete diet on the production performance of crossbred cows. Indian Journal of Animal Sciences 66:63-67.

Reddy, G.V.N., P. Dipti Wilhelmina, and Reddy, M.S 2003. Effect of differently processed complete diet on performance of Murrah buffalo. Indian Journal of Animal Nutrition 20(2): 131-135.

Snedecor, G.W., and Cochran, W.C. 1976. Statistical Methods, $7^{\text {th }}$ Edn, Oxford and IBH Publishing Company, Kolkata.

Sreedhar, V., E. Raghava Rao and Krishna, N. 1997. Palm press fibre, a potential byproduct of oil palm processing as a substitute for paddy straw in buffaloes. Proceedings of VIII Animal Nutrition Conference held at Chennai from $12^{\text {th }}$ $14^{\text {th }}$ December, 1997.

\section{How to cite this article:}

Pakala Venkata, S.B., R. Prasanna Kumar, M. Sahitya Rani and Raghava Rao, E. 2018. Utilization of Sugarcane By-Products as Complete Rations for Milk Production in Buffaloes. Int.J.Curr.Microbiol.App.Sci. 7(02): 3111-3117. doi: https://doi.org/10.20546/ijcmas.2018.702.374 